\title{
Albinism in Natrix tessellata (Serpentes: Natricidae)
}

\author{
Simona Papezikova, ${ }^{1}$ Milan Oselsky, ${ }^{2}$ Petr Papezik, ${ }^{1}$ and Daniel Jablonski ${ }^{1}$ \\ ${ }^{1}$ Department of Zoology, Comenius University in Bratislava, Mlynská dolina, Ilkovičova 6, 842 15, Bratislava, Slovakia. \\ E-mail: daniel.jablonski@balcanica.cz. \\ ${ }^{2}$ Košická Belá 274, 04465 Košická Belá, Slovakia; Herpetolog.sk.
}

\begin{abstract}
Albinism in Natrix tessellata (Serpentes: Natricidae). The Dice Snake, Natrix tessellata, varies in color and pattern, and has several color morphs. Except for melanism, color aberrations are quite rare in the species. Of the two published records of albinism in $N$. tessellata, the first, from the mid-19 $19^{\text {th }}$ century in Italy is dubious; the second is from Israel. Herein, albinism in juvenile $N$. tessellata from Slovakia is documented, and the occurrence of albinism in all species of European snakes is discussed.
\end{abstract}

Keywords: Central Europe, color aberration, Dice Snake, European snakes, Natricinae.

\begin{abstract}
Resumo
Albinismo em Natrix tessellata (Serpentes: Natricidae). Natrix tessellata varia em cor e padrão e tem várias formas de cores. Exceto pelo melanismo, as aberrações cromáticas são muito raras na espécie. Dos dois registros de albinismo publicados para essa espécie, o primeiro, de meados do século 19 na Itália, é duvidoso; o segundo é de Israel. Documentamos aqui o albinismo em jovens de $N$. tessellata da Eslováquia e examinamos o contexto de albinismo observado entre outras serpentes da Europa.
\end{abstract}

Palavras-chave: aberração cromática, albinismo, Europa Central, Natricinae, serpentes européias.

\section{Introduction}

Natrix tessellata (Laurenti, 1768) comprises nine mitochondrial evolutionary lineages that have a rather uniform morphology (Mebert 2011) across the wide range of the species (Guicking et al. 2009). It is one of the most common semiaquatic snake species in the western Palearctic (Gruschwitz et al. 1999) belonging to the family Natricidae (Zaher et al. 2019); it inhabits watercourses with mostly

Received 27 April 2020

Accepted 14 July 2020

Distributed December 2020 rocky shores (Conelli et al. 2011) and feeds mainly on fish or amphibians (Frotzler et al. 2011, Storm 2018). The species is known for its color and pattern variation in natural populations (Sterijovski et al. 2011), including different color morphs (e.g., uniformly brown or yellowish), and except for melanism, color aberrations are rare (e.g., In den Bosch et al. 1998, Sterijovski et al. 2011, Tuniyev et al. 2011).

To date, only two albinotic individuals of Natrix tessellata have been reported-one from Italy and one from Israel. The albinotic juvenile snake from Kfer Netter, Israel, was found alive; other than a photograph, no further information 
was provided by Werner (2016: 268). The snake from Italy was found by Riccardo Magnani on 09 August 1879 at Cantone delle Tre Miglia, near Pavia in northern Italy. It is a male with a snout-vent length of $44.5 \mathrm{~cm}$ and tail length of $11.5 \mathrm{~cm}$ (total length, $55 \mathrm{~cm}$ ). The specimen has two preocular, three postocular, and eight supralabial scales (Razzetti in litt. 2018). Pirotta (1879) described it to be pinkish in color with two darker spots on the scales on the top of the head, and slight brownish shades on ventral and subcaudal scales. However, leucism cannot be excluded in this case as the original author Mr. Magnani placed the specimen in alcohol, believing it a venomous species. After a few hours in alcohol, Pirotta (1879) could not recognize the color of the iris; this led Pirotta (1879) to consider the specimen as either leucistic or albinotic. The snake is deposited in the zoological collection of the museum in the Natural History Museum in Pavia, under voucher number CR0373 (Figure 1).
The first record of albinism in N. tessellata from Slovakia reported here is important. Although albinism occurs in all vertebrates, it is rare in wild populations, especially in adults (Ferri and Bettiga 1992). The condition is a genetic anomaly caused by lack of activity of the enzyme tyrosinase, which is responsible for formation of melanin (Creel et al. 1974), resulting in the absence of melanin in the skin, the iris, and the choroid (Spadola and Di Toro 2007, Krecsák 2008). Estimates of the occurrence of albinism in the wild vary from 1:10,000 to 1:30,000 (Bechtel 1995).

\section{Materials and Methods}

On 16 July 2018 at about 18:00 h, an anonymous person informed $\mathrm{MO}$ of a clutch of eggs of Natrix tessellata from Šaca, Slovakia (48 38'38.4" N, 2109'46.8" E; 252 m a.s.1.), where the species is known to occur (Lác and Lechovič 1964). The clutch of 18 eggs was

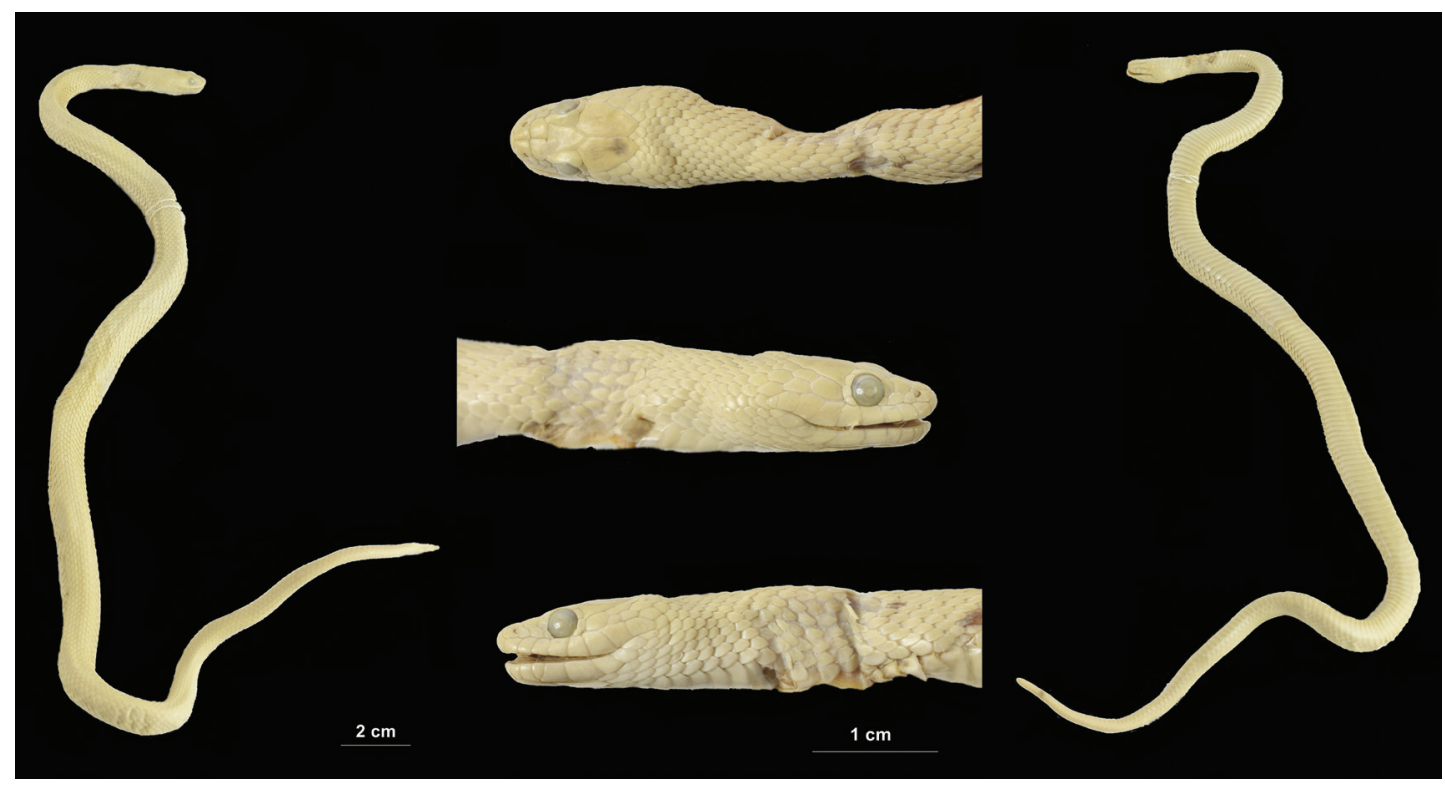

Figure 1. A potentially albinotic individual of Natrix tessellata found in Pavia in 1879 and deposited in the Natural History Museum in Pavia, Italy (voucher no. CR0373). 
between wooden boards to be used for construction. Three mold-infested, unfertilized eggs were removed from the clutch, and the rest of the eggs were placed in an incubator. During incubation (moist vermiculite; $26^{\circ} \mathrm{C} ; 60-70 \%$ humidity), two eggs started to rot and were removed on 20 and 23 July 2018. On 11 August 2018, 13 hatchlings, eight normally colored and five albinos, hatched after 26 days inside the incubator. The incubation period for $N$. tessellata eggs for Central Europe is 41-72 days (Velenský et al. 2011). All individuals are kept in plastic boxes with pine bark. Each box also contains a large water bowl, a shelter, and a branch of appropriate size. Photoperiod and heating are provided by heat lamps with temperatures reaching up to $28^{\circ} \mathrm{C}$ in a basking spot and room temperature in other parts of the enclosure. Individuals are fed separately every 7-10 days on aquarium fish provided by local breeders. The eggs were collected and maintained in captivity under permit number 10783/2018-6.3 from the Ministry of Environment of the Slovak Republic-Directorate for Nature, Biodiversity and Landscape Protection. Blood samples were taken from all individuals and each has its voucher number (DJ8522-8534), deposited in the collection of the Department of Zoology, Comenius University in Bratislava.

Morphometric and meristic data for all snakes were recorded $1 \mathrm{wk}$ after the snakes hatched. The following measurements were taken by SP with a digital caliper to the nearest $0.1 \mathrm{~mm}$ : head length (HL), head width (HW), mouth length (ML). Snout-vent length (SVL), tail length (TL) and total length (TotL $=\mathrm{SVL}+$ TL) were measured using a tailor's tape measure. The following meristic characters were recorded: preocular (PREOC), postocular (POSTOC), supralabial (SUPL), sublabial (SUBL), ventral (VENT), subcaudal scales (SUBC) and dorsal scale row (DORS), following the methods of Moravec (2015). We also documented possible anomalies in scalation. All individuals were photographed 30 days after hatching from the dorsal and ventral sides and close up photographs of the head from upper, bottom and lateral side were taken. Detailed photos of five albino individuals are presented in Appendix I. Six individuals [two albinotic (DJ8524, DJ8526) and four normally colored (DJ8530-8532, DJ8534)], died independently within 5 mo after hatching. One year after hatching, the remaining living individuals were measured (Table 1). We compared all metric and meristic characters with results of Laňka (1973) and Opoldusová (2008) and with our own data for $N$. tessellata from Slovakia. At the time of this writing (April 2020), three albinotic and four normal individuals are being kept in captivity.

To compare rarity of albinism in other European species of snakes, we reviewed and summarized published and unpublished (observations from field herpetologists supported by a photo; Appendix II) data about albinotic snakes (Table 2).

\section{Results}

Albinotic individuals from Šaca, Slovakia, have unpigmented, pinkish skin, and reddish eyes lacking pigmentation (Figure 2; Appendix I). Darker pinkish spots are present on cephalic scales, mainly on the parietal, frontal and supraocular scales. The inverted V-pattern behind the head is not as visible as it is in normally colored individuals, but darker spots occur on a few scales in that region. There is a ventral pattern of alternating yellowish and pinkish spots in each albino snake (Figure 2).

At hatching, all juvenile $N$. tessellata-both albinotic and normally colored-had relatively similar SVL and head measurements (HL, HW, and ML), but TL differed sexually. Mean SVL of newly hatched juveniles was $23.27 \mathrm{~cm}$ (range 21.40-24.00; SD \pm 0.63). Similarly, mean TL was $6.16 \mathrm{~cm}$ (range $5.40-6.80 ; \mathrm{SD} \pm 0.46$ ). Of the13 hatchlings, seven were males and six females; a total of five was albinotic-four males and one female. All metric and meristic data are summarized in Table 1. There were no anomalies in the numbers of PREOC and POSTOC scales. 
Papezikova et al.
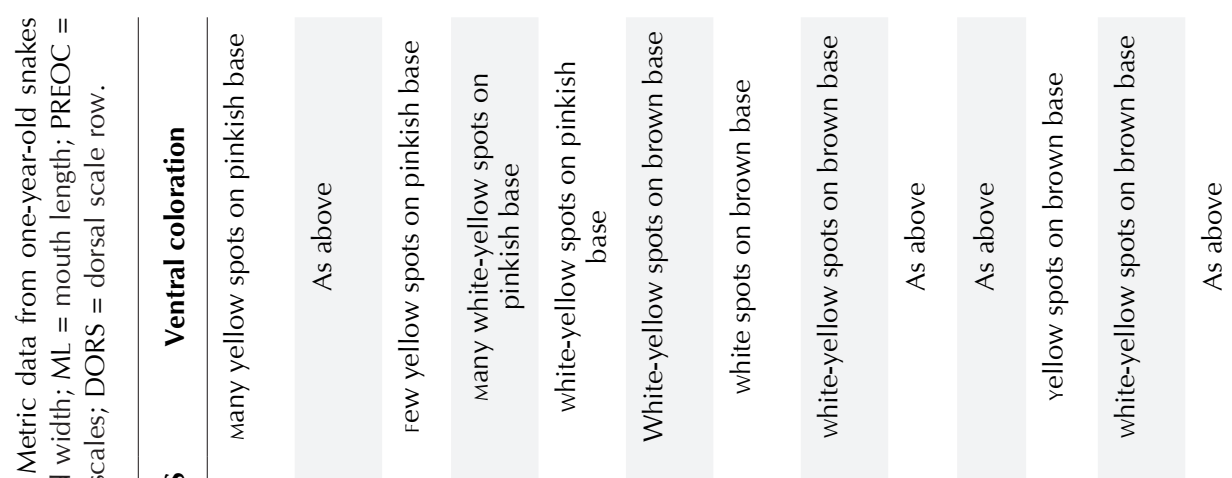

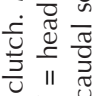

ڤัต

$\stackrel{\circ}{\circ} \stackrel{\circ}{\square}$

$\stackrel{9}{-}$

$\stackrel{\sigma}{\circ} \stackrel{\sigma}{\square}$

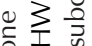

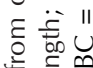

以

蛋

ญ्य

$\stackrel{x}{\stackrel{亠}{亠}}$

之吾出

이은

氞

ह

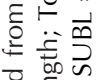

웡 흔

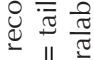

: $\stackrel{0}{=}$

点

흔

ป ट

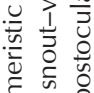

드 "

๘ $\gg \cup$

岁

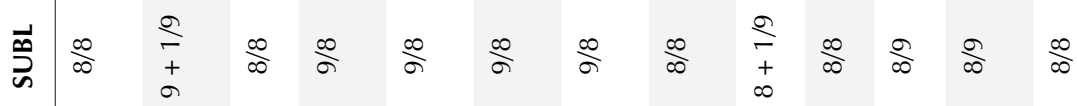

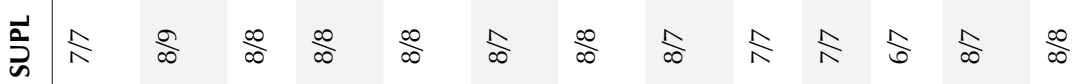

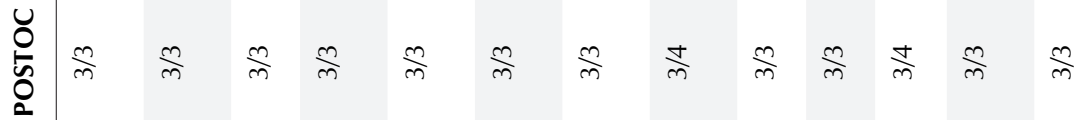

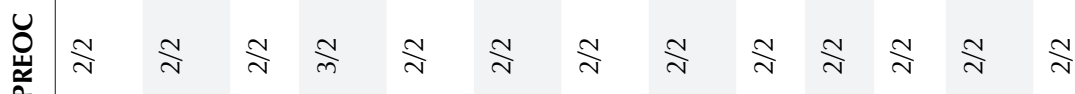

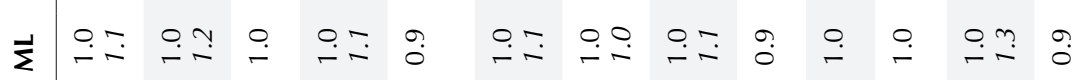

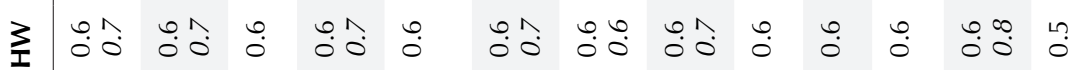

壬

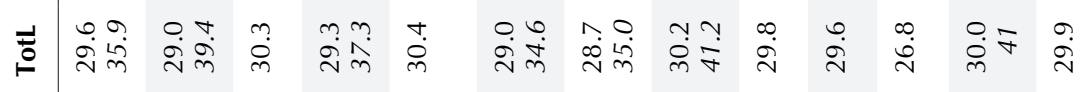

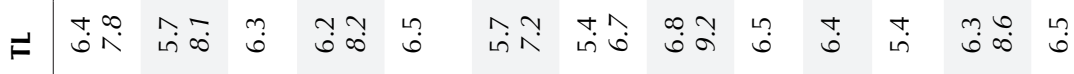

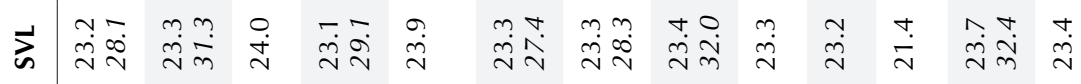

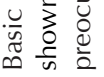

$\frac{\dot{0}}{\frac{0}{\sqrt{0}}}$

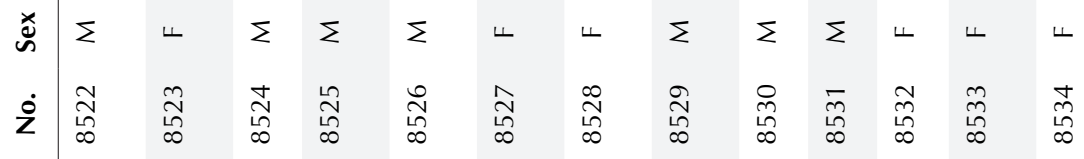


Table 2. List of published and unpublished data recording albinotic species of snakes in Europe; *true albinism not verified. Unpublished observations (in litt. or pers. comm.) are supplemented by photos and presented in Appendix II.

\begin{tabular}{|c|c|c|c|}
\hline Species & $N$ & Country & References \\
\hline \multirow[t]{5}{*}{ Coronella austriaca } & 1 & Austria & Happ 1994 \\
\hline & 2 & Czech Republic & Rehák 1992, B. Trapp (in litt.) \\
\hline & 1 & Italy & Pirotta 1879 \\
\hline & 1 & Netherlands & Lenders 2008 \\
\hline & 1 & Slovakia & D. Revaj (pers. comm.) \\
\hline \multirow[t]{2}{*}{ Coronella girondica } & 1 & France & Geniez and Grillet 1989 \\
\hline & 1 & Spain & Martínez-Silvestre et al. 2009 \\
\hline Dolichophis jugularis & 1 & Cyprus & Baier et al. 2013 \\
\hline Elaphe sauromates & 2 & Bulgaria & Petzold 1975, Jablonski et al. 2019 \\
\hline Hierophis viridiflavus & 1 & Italy & Scali 1992 \\
\hline Malpolon monspessulanus & 1 & Spain & Martínez-Silvestre and Soler 2018 \\
\hline \multirow[t]{2}{*}{ Natrix helvetica } & 2 & France & Baudin 2003, Varanguin 2012 \\
\hline & 1 & U.K. & Boulenger 1913 \\
\hline Natrix maura & 5 & Spain & $\begin{array}{l}\text { Pérez and Collado 1975, Herrador and Pulido } \\
\text { 2006, Alaminos and López 2011, L. Gonzáles } \\
\text { García (in litt.), E.R. Ara (in litt.) }\end{array}$ \\
\hline \multirow[t]{4}{*}{ Natrix natrix } & 1 & Austria & Sackl and Putz 2002 \\
\hline & 1 & Czech Republic & Musilová et al. 2006 \\
\hline & 1 & Germany & M. Bollhorn (in litt.) \\
\hline & 1 & Poland & T. Krajča (pers. comm.) \\
\hline Natrix tessellata* & 1 & Italy & Pirotta 1879 \\
\hline Natrix tessellata & 5 & Slovakia & This study \\
\hline Vipera ammodytes & 1 & Italy & Krecsák 2008 \\
\hline Vipera aspis & 3 & France & Bruno 1985, Naulleau 1997, Guiller 2007 \\
\hline \multirow[t]{6}{*}{ Vipera berus } & 1 & Bulgaria & Stojanov 2014 \\
\hline & 2 & Finland & Vainio 1931, Krecsák 2008 \\
\hline & 1 & Germany & Buchner 1917 \\
\hline & 2 & Sweden & Edelstam 1971, Krecsák 2008 \\
\hline & 1 & Slovakia & Gezova et al. 2018 \\
\hline & 4 & U.K. & Leighton 1901, Harris 1936, Krecsák 2008 \\
\hline \multirow[t]{7}{*}{ Zamenis longissimus } & 3 & Austria & Erber 1879, Sochurek 1955, Esterbauer 2014 \\
\hline & 1 & Bosnia \& Herzegovina & Ćurić 2019 \\
\hline & 1 & Italy & Ferri and Bettiga 1992 \\
\hline & 1 & Serbia & Radovanović 1941 \\
\hline & 8 & Slovakia & $\begin{array}{l}\text { Balthasar 1935, Gabzdil 2003, Musilová et al. } \\
\text { 2006, Gezova et al. 2018, S. Kl'účiková-Píšová (in } \\
\text { litt.), D. Revaj (pers. comm.), L'. Magyariová and } \\
\text { S. Bánovský (in litt.) }\end{array}$ \\
\hline & 1 & Slovenia & Krofel 2004 \\
\hline & 1 & Switzerland & Bruno and Maugeri 1990 \\
\hline Zamenis scalaris & 4 & Spain & $\begin{array}{c}\text { Rollinat 1934, Lesparre 2001, Manjón 2011, D. } \\
\text { Lerena and R.C. Zárate (in litt.) }\end{array}$ \\
\hline
\end{tabular}



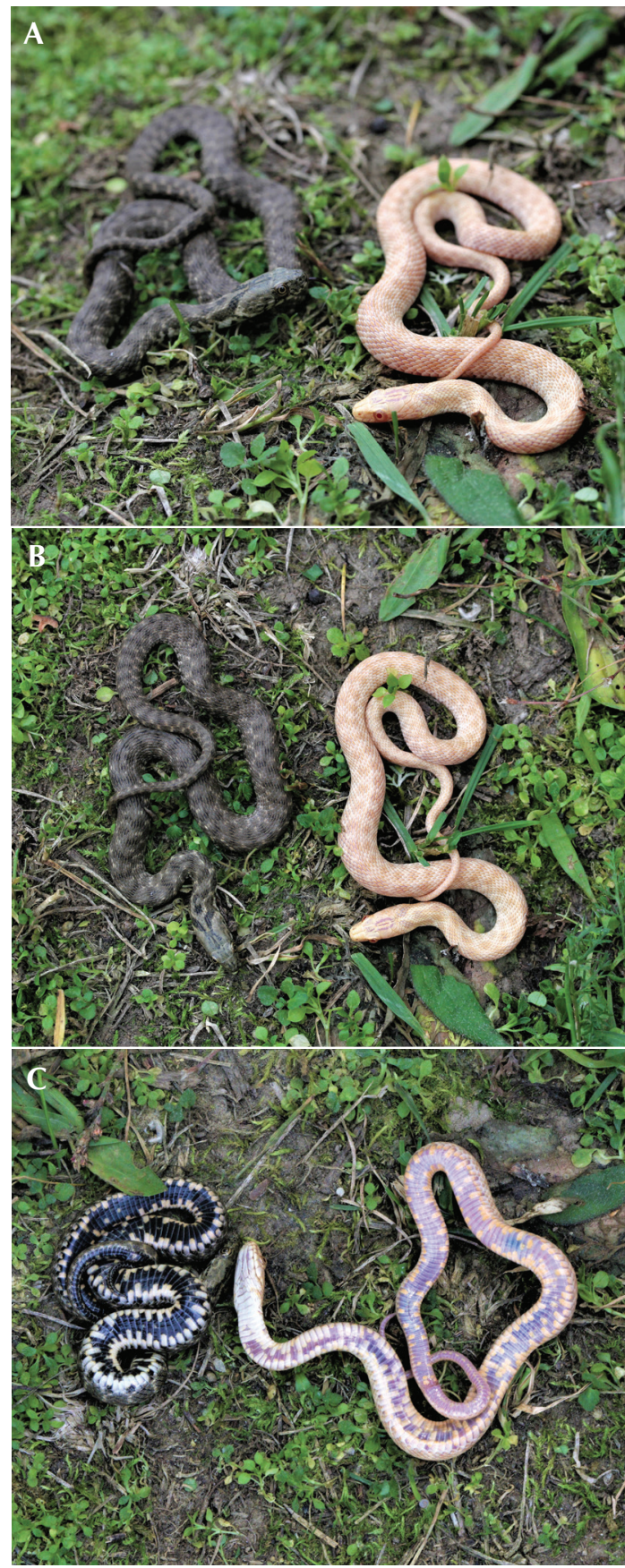

Figure 2. Comparison of normally colored and albinotic hatchlings of Natrix tessellata from Šaca, Košice, Slovakia: frontal (A), dorsal (B), and ventral $(\mathbf{C})$ views.
However, the following anomalies in scalation were observed in 11 of the 13 individuals: fused SUPL in DJ8522; fused SUBL in DJ8533; inserted SUBL in DJ8523 and DJ8530; fused SUBC in DJ8522-8524, DJ8526, DJ8529, and DJ8531; inserted VENT in DJ8527 and DJ85318533; and split VENT in DJ8528 (numbers listed in Table 1).

We found records of a total of 65 truly albinotic snakes representing four families and eight genera in Europe (Table 2); this total includes the five juveniles from Šaca, Slovakia, as a new record for Europe. The total excludes the dubious record of $N$. tessellata (CR0373) from Pavia, Italy, as well as the albinotic Israelic snake (Werner 2016). Among the albinotic snakes recorded in Europe, the genus Zamenis contains the most albinos (20 individuals, representing $\sim 33 \%$ of the total; the five individuals from Šaca were excluded from this calculation because they were found as eggs and hatched in captivity), which were found in eight countries. Only one albino snake is recorded for each of the genera Dolichophis (Cyprus), Hierophis (Italy), and Malpolon (Spain). Spain has the greatest number of albinotic snakes; a total of 11 individuals of four species is knownCoronella girondica (Daudin, 1803), Malpolon monspessulanus (Hermann, 1804), Natrix maura (Linnaeus, 1758), and Zamenis scalaris (Schinz, 1822). Each of the following countries has only one record of an albino snake: the Netherlands, Bosnia and Herzegovina, Cyprus, Poland, Serbia, Slovenia, and Switzerland. In the genus Natrix, albino individuals occur in almost all species [viz., N. natrix (Linnaeus, 1758), N. helvetica (Lacépède, 1789), N. maura, and N. tessellata] with the exception of $N$. astreptophora (Seoane, 1885). Four albino N. natrix were found in each of four countries (Austria, Czech Republic, Germany, and Poland), three N. helvetica in two countries (France and the United Kingdom), and five N. maura in one country (Spain; Table 2). Six truly albinotic $N$. tessellata individuals occur in two countries-one in Israel and five described here from Slovakia (excluding the dubious record from Italy). 


\section{Discussion}

Albinism in snakes is considered to be a rare, autosomal recessive mutation with an expected ratio of normally colored to albinotics of $3: 1$ if mating two heterozygotes (Clay 1935, Bechtel and Bechtel 1985). When mating heterozygotes and homozygotes, the probability of albinotic juveniles is approximately 50\% (Bechtel and Bechtel 1985). When two homozygotes mate then $100 \%$ of offspring will be of the albino phenotype. However, without information on the coloration of unhatched $N$. tessellata, we can only estimate the genotype of the parents; most likely one was a heterozygote and the other a recessive homozygote. The frequency of recessive alleles is greater in small, fragmented populations (Laikre 1999) and that could be the case in this study. The population in eastern Slovakia is at the northern edge of the range of the species (Gezova and Jablonski 2018) and one might assume that populations occurring near the range limits have lower densities and effective population sizes (Vucetich and Waite 2003). The occurrence and survival of albinotic individuals also may be related to abiotic environmental features such as elevation and temperature (Kehas et al. 2005). Moreover, environmental pollution (Kolenda et al. 2017) that may occur in an urban area, such as the one where the egg clutch was found, may be correlated abnormal scutelation in reptiles, but the relationship has not been well studied (Mulder 1995, Cruz-da-Silva et al. 2018 and literature therein). However, anomalous scalation in N. tessellata is not unusual in central Europe (e.g., Laňka 1978, Rehák 1989, Baruš et al. 1992).

Abnormally colored species of snakes may be subject to higher predation pressure by visually oriented predators, and thus, be negatively affected by the lack of pigmentation because they are more easily visible. In addition, reproductive fitness of albino snakes is reduced (Krecsák 2008, McCardle 2012). The lack of pigment in the eyes adversely affects vision; thus, it is more difficult for albino snakes to find suitable prey, avoid danger, and perceive visual signals during mating season (Miller 2005, Krecsák 2008). These facts may partially account for the fact that more albino juveniles were encountered in the wild than adults (e.g., Alaminos and López 2011, Gezova et al. 2018, Martínez-Silvestre and Soler 2018). Nevertheless, albinotic adults of several genera of European snakes, including the genus Natrix, have been observed in the wild (e.g., Sackl and Putz 2002, Krecsák 2008, Alaminos and López 2011, Bruni 2017, Jablonski et al. 2019). Krecsák (2008) posits that there are more aberrant European Viperinae snakes in northern regions than in southern regions; however, we observed the opposite in our review in which the most albinos occurred in central Europe and the Iberian Peninsula with the greatest number of albinos recorded in the genera Zamenis, Vipera, and Natrix. We suggest that there is no clear pattern in albinism in European snakes and that albinotic individuals seem to be distributed randomly in the natural populations. However, ecological, and environmental factors need to be investigated more thoroughly.

\section{Acknowledgments}

We thank Edoardo Razzetti for providing assistance and information about the specimen deposited in the Natural History Museum in Pavia and Alessandra Pandolfi for providing photos of this snake. We also thank E. R. Ara, Š. Bánovský, M. Bollhorn, L. Gonzáles García, D. Jandzík, S. Klúčiková-Píšová, T. Krajča, D. Lerena, M. Lukanová, L. Magyariová, D. Revaj, B. Trapp, and R. C. Zárate for notes and photos of albinotic snake species recorded in Europe. The Ministry of Environment of Slovak Republic, Directorate for Nature Biodiversity and Landscape Protection granted permission to keep individuals from Šaca. We are also grateful to L. Trueb and R. Morgan for English corrections, and associate editor Ross D. MacCulloch and two anonymous reviewers for 
comments which improved the first version of the manuscript. This work was supported by the Slovak Research and Development agency, contracts no. APVV-15-0147 and APVV-190076.

\section{References}

Alaminos, E. A. and J. J. L. López. 2011. Un caso de albinismo en Natrix maura en el sur de la Península Ibérica. Boletín de la Asociación Herpetológica Española 22: 81-82.

Baier, F., D. J. Sparrow, and H. J. Wiedl (eds.). 2013. The Amphibians and Reptiles of Cyprus. Frankfurt am Main. Edition Chimaira. 362 pp.

Balthasar, V. 1935. Několik pozurohodných objektů herpetologické sbírky Slovenského vlastivědného muzea v Bratislavě. Vědy př́rodní 16: 67-68.

Baruš, V., M. Kminiak, B. Král, O. Oliva, E. Opatrný, I. Rehák, P. Roth, Z. Špinar, and L. Vojtková (eds.). 1992. Plazi - Reptilia. Praha. Fauna ČSFR 26, Academia. 224 pp.

Baudin, B. 2003 Observation en Mayenne d'une couleuvre à collier albinos (Natrix natrix helvetica). Biotopes 21: $39-40$.

Bechtel, H. B. (ed.). 1995. Reptile and Amphibian Variants: Colors, Patterns and Scales. Malabar. Krieger Publishing Company. 206 pp.

Bechtel, H. B. and E. Bechtel. 1985. Genetics of color mutations in the snake, Elaphe obsoleta. Journal of Heredity 76: 7-11.

Boulenger, G. A. (ed.). 1913. The Snakes of Europe. London. Methusen \& Co. Ltd. 350 pp.

Bruni, G. 2017. A leucistic grass snake Natrix natrix (Linnaeus, 1758) (Serpentes: Natricidae) from Tuscany, Central Italy. Herpetology Notes 10: 313-316.

Bruno, S. (ed.). 1985. Le Vipere d'Italia e d'Europa. Bologna. Edagricole. 270 pp.

Bruno, S. and S. Maugeri (eds.). 1990. Serpenti d'Italia e d'Europa. Milano. Giorgio Mondadori Editore. 207 pp.

Buchner, O. 1917. Über besonders merkvürdige Färbungsvarietäten der Kreuzotter nebst ergänzenden Mitteilungen über das Vorkommen und die Verbreitung derselben Würtemberg, sowie über das Naturell der Giftschlangen. Jahreshefte des Vereins für Vaterländische Naturkunde in Württemberg 1917: 1022.
Clay, W. 1935. The Occurrence of albinos in a brood of the Common Water Snake, Natrix sipedon sipedon (L.). Copeia 1935: 115-118.

Conelli, A. E., M. Nembrini, and K. Mebert. 2011. Different habitat use of Dice Snakes, Natrix tessellata, among three populations in Canton Ticino, Switzerland. A radiotelemetry study. Mertensiella 18: 100-116.

Creel, D., C. J. Witkop, and R. A. King. 1974. Asymmetric visually evoked potentials in human albinos: evidence for visual system anomalies. Investigaitive Ophthalmology 13: $430-440$.

Cruz-da-Silva, R. C., M. A. de Freitas, and A. D. Abegg. 2018. A remarkable specimen of the genus Anilius (Serpentes: Aniliidae): rare colour aberration or a new species? Herpetology Notes 11: 161-165.

Ćurić, A. 2019. Albinism of Aesculapian snake Zamenis longissimus (Laurenti, 1768) in situ: first record for Bosnia and Herzegovina. Natura Sloveniae 21: 31-33.

Edelstam, C. 1971. White adders. Animals: The International Wildlife Magazin 13: 896-897.

Erber, J. 1879. Einen Albino der Aesculapnatter (Elaphis aesculapii). Verhandlungen der Zoologisch-Botanischen Gesellschaft in Wien 29: 39-40.

Esterbauer, H. 2014. Die Äskulapnatter, Zamenis longissimus (Laurenti, 1768). Erstnachweis einer amelanistischen Farbmutation in Österreich. Ein Porträt der Äskulapnatter in Verbindung mit dem Erstnachweis einer ,weißen“ Farbvariante in Österreich liefert der Reptilienfachmann. ÖKO L 36: 7-11.

Ferri, V. and M. Bettiga. 1992. Un caso di albinismo nel Colubro di Esculapio, Elaphe l. longissima (Laurenti, 1768). Il Naturalista Valtellinese. Atti del Museo Civico di Storia Naturale di Morbegno 3: 91-96.

Frotzler, N., N. Davitashvili, and K. Mebert. 2011. Distribution of the Dice Snake (Natrix tessellata) in Georgia (Transcaucasia) and comparative notes on the genus Natrix. Mertensiella 18: 357-364.

Gabzdil, R. 2003. Svetový unikát na výstave. Extra Zemplín, Nezávislý týždenník občanov okresov Michalovce, Trebišov a Sobrance 10: 2.

Geniez, P. and P. Grillet (eds.). 1989. Les Couleuvres et Les Viperes. Lausanne. Editions Payot. 64 pp.

Gezova, S. and D. Jablonski. 2018. Range extension and highest elevational populations of Natrix tessellate in Slovakia. Amphibian and Reptile Conservation 12: 98105.

Gezova, S., P. Drugac, A. Purkart, and D. Jablonski. 2018. Albinism in two snake species recorded from Slovakia. Russian Journal of Herpetology 25: 79-82. 
Gruschwitz, M., S. Lenz, K. Mebert, and V. Laňka. 1999 Natrix tessellata (Laurenti, 1768) - Wurfelnatter. Pp. 581-644 in W. Böhme (ed.), Handbuch der Reptilien und Amphibien Europas. Band 3/IIA: Schlangen II. Wiesbaden. AULA-Verlag.

Guicking, D., U. Joger, and M. Wink. 2009. Cryptic diversity in a Eurasian water snake (Natrix tessellata, Serpentes: Colubridae): evidence from mitochondrial sequence data and nuclear ISSR PCR fingerprinting. Organisms, Diversity and Evolution 9: 201-214.

Guiller, G. 2007. Un spécimen albinos de Vipera aspis (Linnaeus, 1758) découvert dans 1'Ouest de la France. Bulletin de la Société des Sciences naturelles de l'Ouest de la France 29: 1-6.

Happ, F. 1994. Fund einer Albino-Schlingnatter (Coronella austriaca austriaca Laurenti, 1768) auf dem Magdalensberg in Kärnten. Carinthia II 184: 123-129.

Harris, G. T. (ed.). 1936. Albino adder. Axminster. Report and Transactions of the Devonshire Association for the Advancement of Science, Literature and Art. 134 pp.

Herrador, F. C. and L. P. Pulido. 2006. Albinismo e hipomelanismo en Culebra viperina. Butlletí de la Societat Catalana d'Herpetologia 17: 53-55.

In den Bosch, H., W. Bischoff, and J. F. Schmidtler. 1998. Bemerkenswerte Reptilienfunde im Libanon. Herpetofauna 20: 19-32.

Jablonski, D., J. Jankov, K. Bedev, and N. Natchev. 2019. Albinism in Elaphe sauromates. Herpetological Bulletin 149: 46.

Kehas, A. J., K. Theoharides, and J. Gilbert. 2005. Effect of sunlight intensity and albinism on the covering response of the Caribbean Sea urchin Tripneustes ventricosus. Marine Biology 146: 1111-1117.

Krecsák, L. 2008. Albinism and leucism among European Viperinae: a review. Russian Journal of Herpetology 15: $97-102$.

Kolenda, K., B. Najbar, A. Najbar, P. Kaczmarek, M. Kaczmarski, and T. Skawiński. 2017. Rare colour aberrations and anomalies of amphibians and reptiles recorded in Poland. Herpetology Notes 10: 103-109.

Krofel, M. 2004. First record of albino Aesculapian Snake (Elaphe longissima) in Slovenia. Natura Sloveniae 6: 53-56.

Lác, J. and A. Lechovič. 1964. Historický prehl’ad výskumu plazov na území Slovenska do roku 1963. Acta Rerum Naturalium Musei Nationalis Slovaci 10: 124-154.

Laikre, L. 1999. Hereditery defects and conservation genetic management of captive populations. Zoo Biology 18: 81-99.
Laňka, V. 1973. Variabilita a biologie užovky podplamaté, Natrix tessellata Laurenti, 1768. Unpublished M.Sc. Dissertation. Charles University, Praha, Czech Republic.

Laňka, V. 1978. Variabilität und Biologie der Würfelnatter (Natrix tessellata). Acta Universitatis Carolinae Biologica 1975-1976: 167-207.

Leighton, G. R. (ed.). 1901. The Life History of British Serpents and Their Local Distribution in the British Isles. Edinburgh and London. William Blackwood and Sons. 448 pp.

Lenders, A. J. W. 2008. Opnieuw een albino Gladde slang in de Meinweg. Natuurhistorisch Maandblad 97: 139.

Lesparre, D. 2001. Un caso de albinismo en culebra de escalera (Elaphe scalaris). Boletín de la Asociación Herpetologica Espańola 12: 17-18.

Manjón, N. 2011. Caso de albinismo total en Rhinechis scalaris. Boletín de la Asociación Herpetológica Española 22: 77-78.

Martínez-Silvestre, A. and J. Soler. 2018. Caso de albinismo en Malpolon monspessulanus (Hermann, 1804). Boletín de la Asociación Herpetológica Española 29: 31-33.

Martínez-Silvestre, A., J. Soler, J. M. Ş. Gener, M. García, and C. Martí. 2009. Albinismo total de Coronella girondica en la Península Ibérica. Boletín de la Asociación Herpetológica Española 20: 44-45.

McCardle, H. 2012. Albinism in wild vertebrates. Unpublished M.Sc. Dissertation. University of San Marcos, Texas, USA.

Mebert, K. 2011. Geographic variation of morphological characters in the Dice Snake (Natrix tessellata). Mertensiella 18: 11-19.

Miller, J. D. 2005. All about albinism. Missouri Conservationist 66: 4-7.

Moravec, J. 2015. Natrix tessellata (Laurenti, 1768) - užovka podplamatá. Pp. 364-395 in J. Moravec (ed.), Fauna $\check{C}$ R. Plazi - Reptilia. Praha. Academia.

Mulder, J. 1995. Congenital anomalies in morphology and colour in captive-bred Vipers (Reptilia, Serpentes, Viperidae). Deinsea 2: 41-50.

Musilová, R., V. Zavadil, and P. Kotlík. 2006. Albinismus užovky obojkové. Živa 5: 228-229.

Naulleau, G. (ed.). 1997. La Vipére Aspic. Saint Yrieix. Éveil Nature. 72 pp.

Opoldusová, Z. 2008. Sexuálny dimorfizmus Natrix tessellata (Colubridae, Reptilia). Unpublished M.Sc. Dissertation. Comenius University, Bratislava, Slovakia. 
Pérez, M. and E. Collado. 1975. Hallazgo de Natrix maura albina. Acta Vertebrata 2: 271-272.

Petzold, H. G. 1975. Eine albinotische Vierstreifennatter, Elaphe quatuorlineata sauromates, aus Bulgarien. Salamandra 11: 113-118.

Pirotta, R. 1879. Di alcuni casi di albinismo nei Rettili. Atti della Societa Italiana di Scienze Naturali 21: 1-4.

Radovanović, M. 1941. Zur Kenntnis der Herpetofauna des Balkans. Zoologischer Anzeiger 136: 145-159.

Rehák, I. 1989. Revize fauny hadů Československa. Unpublished Ph.D Thesis. Charles University, Prague, Czech Republic.

Rehák, I. 1992. Coronella austriaca Laurenti, 1768 - Užovka hladká. Pp. 134-140 in V. Baruš, O. Oliva, M. Kminiak, B. Král, E. Opatrný, I. Rehák, P. Roth, Z. Špinar, and L. Vojtková (eds.), Fauna ČSFR. sv. 26. Plazi - Reptilia. Praha. Academia.

Rollinat, R (ed.). 1934. La Vie des Reptiles de la France Centrale. Paris. Delegrave. 343 pp.

Sackl, P. and J. Putz. 2002. Eine albinotische Ringelnatter, Natrix natrix (L.), im steirischen Ennstal, Österreich (Reptilia, Squamata, Colubridae). Joannea Zoologie 4: 11-13.

Scali, S. 1992. Caso di colorazione anomala nel Biacco (Coluber viridiflavus Lacepede, 1789). Atti della Società Italiana di Scienze Naturali e del Museo Civico di Storia Naturale di Milano 133: 294-295.

Sochurek, E. 1955. Die Äskulapnatter Elaphe l. longissima Laurentus 1768 - in Niderösterreich. Unsere Heimat 26: $180-182$.

Spadola, F. and F. Di Toro. 2007. Complete albinism in a Podarcis muralis newborn. Acta Herpetologica 2: 4951.

Sterijovski, B., R. Ajtić, L. Tomović, S. Djordjević, M. Djurakić, A. Golubović, J. Crnobrnja-Isailović, J. M. Ballouard, D. Desmont, F. Groumpf, and X. Bonnet.
2011. Natrix tessellata on Golem Grad, FYR of Macedonia: a natural fortress shelters a prosperous snake population. Mertensiella 18: 298-301.

Stojanov, A. J. 2014. First record of amelanism of Vipera berus bosniensis Boettger, 1889, in Bulgaria. Herpetozoa 26: $180-182$.

Storm, P. 2018. European water snakes and the competitive exclusion principle. Litteratura Serpentium. Jaargang 38: $59-87$.

Tuniyev, B., S. Tuniyev, T. Kirschey, and K. Mebert. 2011. Notes on the Dice Snake (Natrix tessellata) from the Caucasian Isthmus. Mertensiella 18: 343-356.

Vainio, I. 1931. Zur verbreitung und biologie der Kreuzotter, Vipera berus (L.) in Finnland. Annales Societatis Zoologica Botanica Fennica Vanamo 12: 3-19.

Varanguin, N. 2012. Couleuvre à collier - Natrix natrix (Linnaeus, 1758), Ouvrage. Atlas des Reptiles de Bourgogne, Bourgogne Nature, Hors - Série 12: 257-272.

Velenský, M., P. Velenský, and K. Mebert. 2011. Ecology and ethology of Dice Snakes (Natrix tessellata) in the city district Troja, Prague. Mertensiella 18: 157-176.

Vucetich, J. A. and T. A. Waite. 2003. Spatial patterns of demography and genetic processes across the species' range: null hypotheses for landscape conservation genetics. Conservation Genetics 4: 639-645.

Werner, Y. L. (ed.). 2016. Reptile Life in the Land of Israel with Comments on Adjacent Regions. Frankfurt am Main. Edition Chimaira. 494 pp.

Zaher, H., R. W. Murphy, J. C. Arredondo, R. Graboski, P. R. Machado-Filho, K. Mahlow, G. G. Montingelli, A. B. Quadros, N. L. Orlov, M. Wilkinson, Y-P. Zhang, and F. G. Grazziotin. 2019. Large-scale molecular phylogeny, morphology, divergence-time estimation, and the fossil record of advanced caenophidian snakes (Squamata: Serpentes). PLOS ONE 14: e0217959.

Editor: Ross D. MacCulloch 
Appendix I. Albinotic individuals No. 8522-8526 from Šaca, Košice. Head in lateral (A, B), dorsal (C) and ventral $(\boldsymbol{D})$ views. Dorsal $(\boldsymbol{E})$ and ventral $(\boldsymbol{F})$ views of body. Numbers of individuals written below correspond to the numbers listed in Table 1.

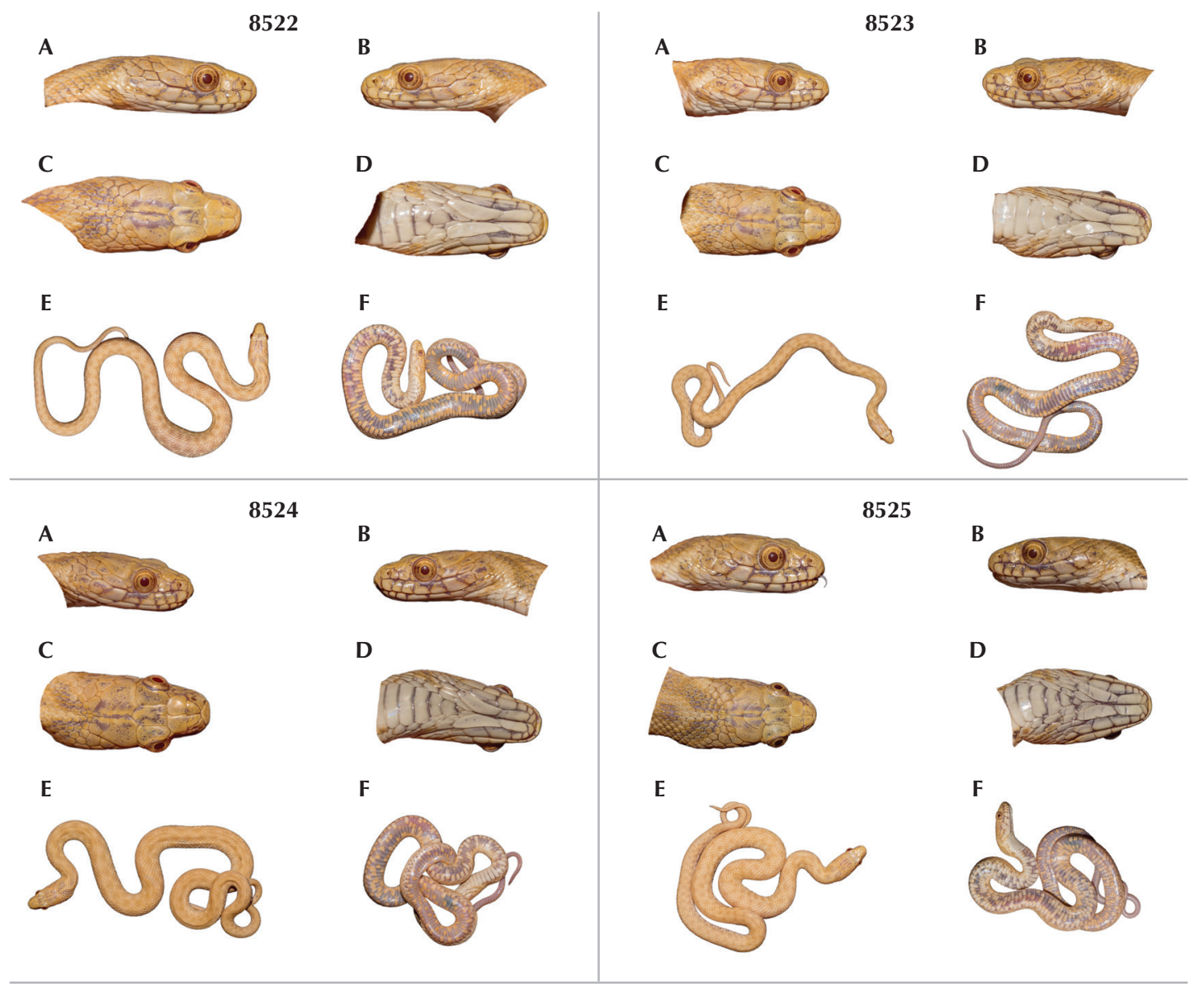

B

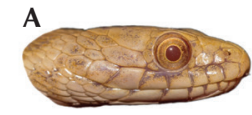

B

C

D
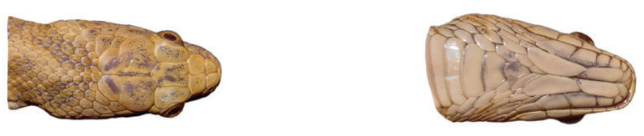

$\mathbf{E}$

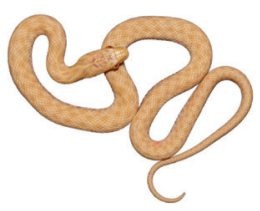

F

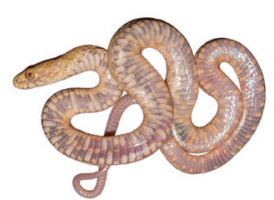


Papezikova et al.

Appendix II. Previously unpublished photographs of albinotic snakes from Europe. (A) Coronella austriaca, Czech Republic (B. Trapp); (B) C. austriaca, Slovakia (D. Revaj); (C) Natrix maura, Spain (L. Gonzáles García); (D) N. maura, Spain (E.R. Ara); (E) Natrix natrix, Germany (M. Bollhorn); (F) N. natrix, Poland (T. Krajča); (G) Zamenis longissimus,

Slovakia (S. Klúčiková-Píšová); (H) Z. longissimus, Slovakia (L. Magyariová and Š. Bánovský);

(I) Z. longissimus, Slovakia (D. Revaj); (J) Zamenis scalaris, Spain (D. Lerena and R.C. Zárate).
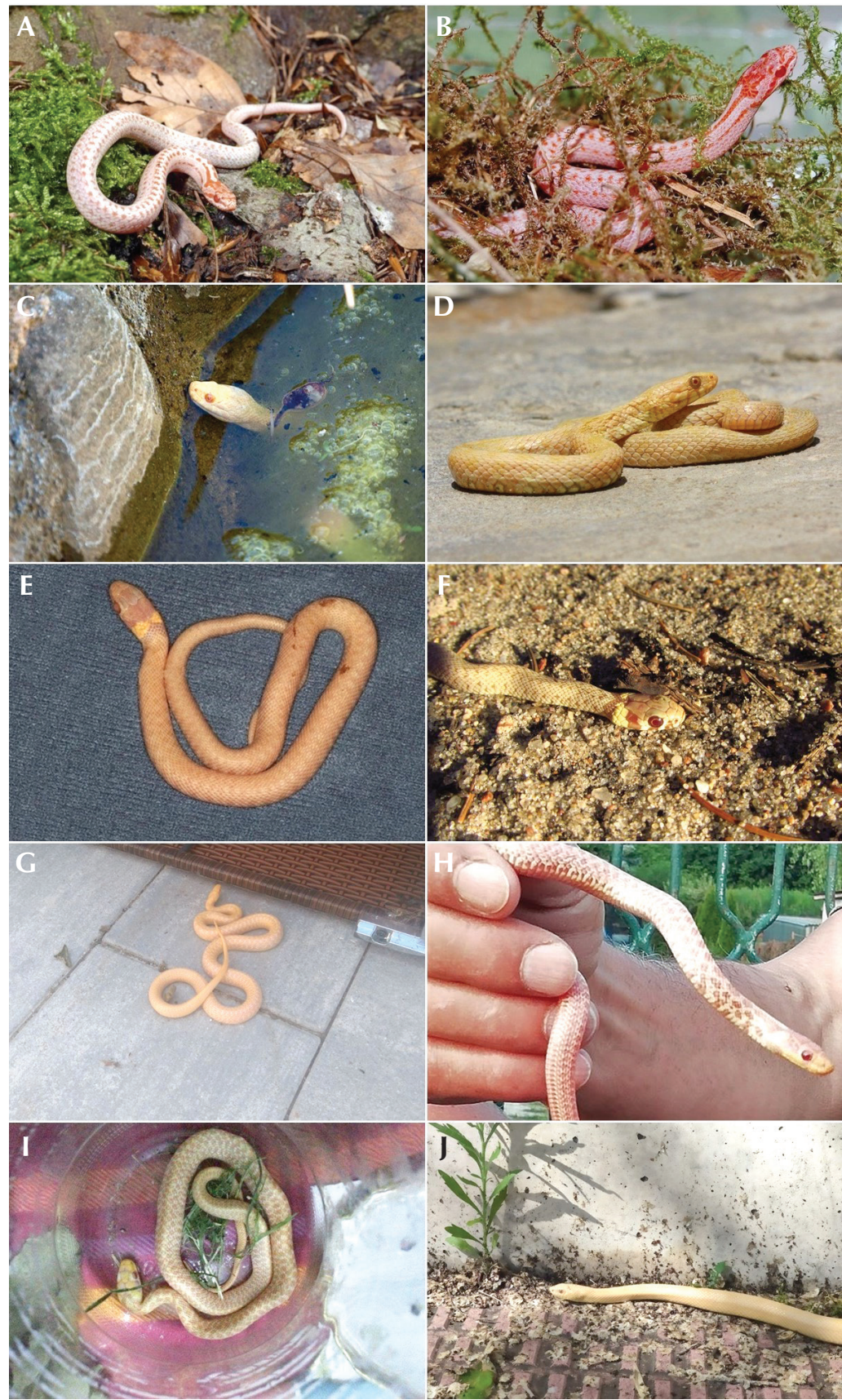